\title{
ANALISIS TINGKAT PERPUTARAN PIUTANG PADA KOPERASI BUMI MANGUPURA SEJAHTERA TAHUN 2012-2014
}

\author{
Luh Putu Diana Pradnyani Putri \\ Jurusan Akuntansi Program Diploma III, \\ Universitas Pendidikan Ganesha, Singaraja \\ e-mail : dianapradnyani@gmail.com
}

\begin{abstract}
Abstrak
Penelitian bertujuan untuk mengetahui: tingkat perputaran piutang pada Koperasi Bumi Mangupura Sejahtera Tahun 2012-2014. Penelitian dilakukan di Koperasi Bumi Mangupura Sejahtera di Jl.Raya Kapal Abianbase. Subjeknya adalah Koperasi Bumi Mangupura Sejahtera dan objek penelitiannya adalah data kredit, data piutang, tingkat perputaran piutang Koperasi Bumi Mangupura Sejahtera. Pengumpulan data yang digunakan adalah wawancara dan studi dokumentasi kemudian dianalisis dengan analisis data deskriptif kuantitatif. Penelitian menunjukkan bahwa: (1) Tingkat perputaran piutang tahun 2012 yaitu sebesar 71,54 kali, dikatakan tingkat perputaran piutang pada tahun 2012 sangat tinggi; Tahun 2013 yaitu sebesar 85,51 kali, tingkat perputaran piutang dapat dikatakan tinggi ; Tahun 2014 tingkat perputaran piutang kembali mengalami penurunan yaitu sebesar 74,89 kali, sehingga dikatakan tingkat perputaran piutang tahun 2014 masih tinggi. (2) Pada tahun 2012 rata-rata pengumpulan piutang berputar selama 5 hari; pada tahun 2013 rata-rata pengumpulan piutang berputar selama 4 hari; pada tahun 2014 rata-rata pengumpulan piutang berputar selama 5 hari
\end{abstract}

Kata Kunci : Piutang, Tingkat perputaran piutang, Koperasi

\section{Abstract}

This study is aimed at investigating the turnover rate of debt in Koperasi Vumi Mangupura Sejahtera in the years of 2012-2014. This study was conducted in Koperasi Bumi Mangupura Sejahtera, which is located on Jalan Raya Kapal Abianbase. The subject of this study is Koperasi Bumi Mangupura Sejahtera and the objects of this study are credit data, debt data, the turnover rate of debt Koperasi Bumi Mangupura Sejahtera. The techniques used for collecting the data are inteview and documentation study that is continued to the analysis of the data with qualitative descriptive analysis. The result shows that (1) the turnover rate of debt in 2012 was 71.54 times, it can be said that the turnover rate of debt in 2012 is very high; in 2013 it was 85.51 times, thus it can be said that the turnover rate of debt is still very high; in 2014 the turnover rate of debt was 74.89 , thus it can be said that the turnover rate of debt in 2014 is relatively high. (2) in 2012, the average of debt collection turnover was 5 days long; in 2013 the average of debt collection turnover was 4 days long; while in 2014 the average of debt collection was 5 days.

Keywords: Debt, The turnover rate of debt, cooperation

\section{Pendahuluan}

Perkembangan dunia usaha semakin meningkat seiring dengan perkembangan zaman. Perusahaan-perusahaan melalui berbagai upaya telah melakukan usaha di semua sector untuk mencapai perkembangan dalam menghadapi persaingan yang semakin ketat. Persaingan merupakan hal yang tidak bisa dihindari dalam kehidupan bisnis terlebih pada era globalisasi karena perusahaan tidak hanya menghadapi persaingan lokal tetapi juga persaingan di tempat regional. Indonesia sebagai salah satu Negara dengan penduduk yang cukup banyak di kawasan asia tenggara merupakan kawasan pasar yang cukup potensial dalam memberikan kredit sehingga diperlukan keterpaduan antara pemerintah dan pihak swasta untuk berperan aktif dalam menunjang pembangunan. 
Sejak terjadinya krisis ekonomi, sosial dan politik pada tahaun 1997 yang dialami oleh bangsa Indonesia membuat pemerintah dan masyarakat terpuruk dan semakin miskin. Jika dicermati dari sudut penyebab kemiskinan dapat disebabkan oleh dua factor. Faktor yang pertama adalah faktor internal yaitu faktor yang ada pada individu, keluarga atau komunitas masyarakat miskin itu sendiri, seperti rendahnya tingkat pendidikan dan tingkat pendapatan. Faktor kedua yaitu faktor eksternal yang di pengaruhi oleh kebijakan global seperti sosial, ekonomi, hukum, politik. Melihat fenomena diatas dapat kita simpulkan dengan keberadaan lembaga keuangan yang bersifat ekonomi kerakyatan seperti koperasi terbukti dapat membantu dalam menyelesaikan permasalahan ekonomi yang terjadi dalam komunitas masyarakat lapisan bawah.

Upaya yang dilakukan dalam hal menganggulangi permasalahan sebagai dampak krisis ekonomi global di Indonesia yaitu peranan koperasi sebagai lembaga yang menghimpun dan menyalurkan dana dari dan untuk anggota koperasi, calon anggota dan masyarakat melalui kegiatan usaha simpan pinjam untuk memberikan fasilitas permodalan dalam sistem kredit, sehingga semakin besar peran koperasi dalam memberikan fasilitas kepada masyarakat maka akan semakin tinggi nilai koperasi di dalam memfasilitasi kehidupan ekonomi bermasyarakat. Oleh karena itu pengelolaan usaha koperasi harus dilakukaan secara professional dan mandiri yang di dukung dengan kualitas sumber daya manusia yang memiliki keahlian dan kemampuan khusus dengan di bantu oleh sistem pengawasan internal yang ketat.

Persaingan yang semakin ketat menuntut koperasi atau perusahaan untuk meningkatkan usahanya terutama menarik konsumen dengan memberikan pelayanan dan pengelolaan secara efektif dan efisien. Salah satu usaha menghadapi permasalahan tersebut dengan adanya kerjasama antara pihak satu dengan pihak lainnya, koperasi satu dengan koperasi lainnya atau masyarakat.

Ada beberapa pengertian analisis menurut para ahli diantaranya menurut Kamus Besar Bahasa Indonesia, analisis adalah penguraian suatu pokok atas berbagai bagiannya dan penelaahan bagian itu sendiri serta hubungan antar bagian untuk memperoleh pengertian yang tepat dan pemahaman arti keseluruhan Menurut Anner Gregory, analisis adalah langkah pertama dari proses perencanaan.Piutang merupakan harta perusahaan atau koperasi yang timbul karena terjadinya transaksi penjualan secara kredit atas barang dan jasa yang dihasilkan oleh perusahaan yang unsure modal kerja yang selalu dalam keadaan berputar.

Anton (1980:52) mengemukakan yang dimaksud dengan piutang adalah sebagai berikut :"piutang adalah unsur modal kerja yang selalu berputar menurut siklus kegiatan perusahaan". Turn over account receivable atau tingkat perputaran piutang pada suatu perusahaan dalam suatu periode tertentu ini sangat penting bagi perusahaan untuk mengetahui perputaran modal dalam piutang. " Tinggi rendanya receivable turnover mempunyai efek langsung terhadap besar kecilnya modal yang di investasikan dalam piutang. Makin tinggi turnover, berarti semakin cepat perputarannya, yang berarti semakin pendek waktu terikatnya modal dalam piutang sehingga jumlah modal dininvestasikan dalam piutang menjadi semakin kecil “ ( Riyanto,2001:91).

Tingkat perputaran piutang merupakan perbandingan antara kredit dengan rata-rata piutang. Tingkat perputaran piutang ini menggambarkan efisien atau tidaknya penggunaan modal oleh perusahaan. Perputaran tersebut akan menentukan besar kecilnya keuntungan yang akan diperoleh perusahaan. Sehingga hal ini akan mempengaruhi operasi perusahaan dimana secara tidak langsung akan berdampak pada tingkat perolehan keuntungan perusahaan yang bersangkutan.

Koperasi merupakan salah satu pelaku ekonomi yang ikut mewarnai wajah perekonomian di Indonesia. Definisi koperasi menurut UU RI No 25 Tahun 1992 tentang perkoperasian pada bab 1 pasal 1 bagian ke satu adalah badan usaha yang beranggotakan orang seorang atau badan hukum koperasi dengan dilandaskan kegiatannnya berdasarkan prinsip koperasi sekaligus gerakan ekonomi rakyat yang berdasarkan atas asas kekeluargaan.

Persaingan yang semakin ketat dan tanpa batas menuntut perusahaan atau koperasi meningkatkan usahanya menarik konsumen dengan berbagai macam cara. Bahkan perekonomian di Indonesia sudah biasa hutang piutang untuk peningkatan usaha agar 
memperoleh apa yang diinginkan. Perekonomian berlandaskan pada demokrasi ekonomi maka masyarakat harus berperan aktif dan berpartisipasi dalam setiap aktifitas pembangunan. Hal ini untuk mendorong perkembangan koperasi, agar mampu menjadi lembaga ekonomi rakyat yang mandiri dan timbul dengan kuat dalam masyarakat.

Berhasil tidaknya koperasi sangatlah berpengaruh terhadap anggotanya, sehingga koperasi dituntut untuk seoptimal mungkin dalam pengelolaan yang sebaik-baiknya dan dilakukan secara professional, khususnya dalam segi keuangan untuk mengetahui kondisi keuangan maka koperasi perlu menyusun laporan keuangannya. Laporan keuangan koperasi pada umumnya terdiri dari neraca, laporan laba rugi tercemin pada perhitungan hasil usaha dan laporan perubahan modal

Kondisi keuangan koperasi merupakan factor utama yang menentukan layak tidaknya suatu koperasi untuk tetap beroperasi. Hal ini menjadi kunci utama karena apabila suatu koperasi mempunyai kondisi financial yang cukup sehat maka masyarakat akan semakin menanamkan kepercayaan pada koperasi tersebut.

Setiap lembaga keuangan seperti koperasi dalam operasional kegiatannya selain menghimpun sumber permodalan juga menyalurkan dana dari dan untuk masyarakat tentunya memilki tujuan yang ingin dicapai yaitu memperoleh keuntungan yang sebesar-besarnya dalam semua kegiatan usahanya yang salah satunya dalam bentuk penyaluran kredit. Setiap lembaga perkreditan tentunya mempunyai asset yang meliputi sumber modal dan penggunaanya. Salah satu bentuk penggunaan modal tersebut yaitu berupa piutang. Piutang adalah kekayaan perusahaan yang paling likuid setelah kas baik kas riil maupun kas di bank.

Piutang berasal dari penjualan kredit yang sudah biasa di lakukan perusahaan atau koperasi pada zaman modern ini untuk menarik dan merangsang minat konsumen. Semakin longgar persyaratan yang diberikan tentunya dengan asumsi langganan tidak merubah kebiasaan membayarnya maka akan semakin besar jumlah piutang. Piutang juga merupakan aktifa lancar yang likuidnya lebih dari persediaan serta merupakan unsur modal kerja yang selalu berputar. Penjualan secara kredit tidak segera menghasilkan penerimaan kas tetapi menimbulkan piutang langganan dan barulah kemudian hari saat jatuh temponya piutang akan terjadi aliran kas masuk (cash inflow) yang berasal dari pengumpulan piutang tersebut. Piutang merupakan elemen modal kerja yang selalu dalam keadaan berputar secara terus menerus. Menurut Indrio dan Basri (1995 : 83) piutang dapat diartikan pula "sebagai aktiva atau kekayaan yang timbul sebagai akibat penjualan secara kredit". Menurut Ikatan Akuntansi Indonesia, Pernyataan Standar Akuntansi Keuangan (PSASK) No 9 : piutang dinyatakan sebesar jumlah kotor tagihan di kurangi dengan taksiran jumlah yang dapat di tagih. Maka koperasi berharap supaya periode perkumpulan piutang sesuai dengan jangka waktu kredit, bahkan dapat dipercepat. Untuk melakukan hal ini, maka dapat diperlukan suatu strategi yang harus dilakukan agar tidak terjadi penyimpangan atas penjualan kredit, sehingga dapat mencapai pengumpulan piutang yang efisien dan efektif. Factor-faktor yang perlu dipertimbangkan dalam kebijaksanaan penjualan kredit : (1) standar kredit atau kualitas langganan yang akan diperkenankan memperoleh kredit; (2) jangka waktu kredit, yaitu berapa lama seorang langganan yang meembeli secara kredit harus sudah membayar hutangnya; dan (3)Potongan atau diskon ( discount ) yang diberikan pada langganan. Ketiga factor tersebut akan menentukan berapa jumlah piutang yang akan di miliki , berapa lama piutang tersebut diharapkan akan terkumpul dan berapa besar piutang yang akan tidak terbayar.

Suatu lembaga keuangan seperti koperasi dapat menganalisa tingakat perputaran piutang dan rata-rata pengumpulan piutang dari beberapa periode dengan menggunakan standar yang telah diterapkan . tingkat perputaran piutang dapat diukur dengan cara membagi jumlah kredit yang telah diberikan dengan piutang rata-rata, sedangkan piutang rata-rata dapat diketahui dengan cara piutang awal ditambah dengan piutang akhir kemudian dibagi dua. Tingkat perputaran piutang juga merupakan rasio untuk melihat seberapa lama piutang berubah menjadi kas. Piutang adalah tagihan kepada pihak lain dengan menerima uang tunai di masa yang akan datang karena pinjaman kredit, salah satunya adalah piutang pada Koperasi Bumi Mangupura Sejahtera. Periode perputaran piutang dilihat dari syarat pembayaran kredit, yaitu panjang pendeknya waktu yang disyaratkan. Semakin tinggi tingkat perputaran piutang 
maka profitabilitas Koperasi Bumi Mangupura Sejahtera semakin meningkat. Begitu juga sebaliknya, semakin rendah tingkat perputaran piutang maka profitabilitas Koperasi Bumi Mangupura Sejahtera semakin rendah. Berdasarkan latar belakang yang diuraikan diatas, maka yang menjadi pokok permasalahan adalah Bagaimanakah tingkat perputaran piutang pada Koperasi Bumi Mangupura Sejahtera Tahun 2012-2014?

\section{Metode Penelitian}

Jenis data yang digunakan adalah data kuantitatif. data kuantitatif adalah jenis data yang berupa angka-angka (dapat diukur dan di hitung). Data kuantitatif dalam penelitian ini adalah data pemberian kredit, dan data piutang Koperasi Bumi Mangupura Sejahtera.

Data-data tersebut diambil dan dikumpulkan dengan metode wawancara dan studi dokumentasi. Wawancara yaitu pengumpulan data dengan cara Tanya jawab langsung terhadap pihak terkait pada Koperasi Bumi Mangupura Sejahtera. Teknik pengumpulan data ini merupakan wawancara langsung atau Tanya jawab dengan pimpinan dan staf pegawai. Metode pengumpulan data lainnya studi dokumentasi. Studi dokumentasi mengumpulkan data melalaui pengitipan catatan atau dokumen yang relevan seperti laporan keuangan agar sesuai dengan tujuan penelitian yang dilakukan. Dari data yang telah terkumpul akan di analisa dengan menggunakan teknik analisis deskriptif kuantitatif yang menggunakan ukuran antara lain berupa

a. Analisis tingkat perputaran piutang

Menurut Sutrisno (2003.64) adalah suatu analisis perputaran piutang digunakan untuk mengukur tingkat efesiensi piutang perusahaan, yang dapat dihitung dengan rumus :

Tingkat Perputaran Piutang $=\frac{\text { Kredit Pertahun }}{\text { Rata }- \text { rata Piutang }}$
Rata - rata piutang $=\frac{\text { Piutang Awal }+ \text { Piutang Akhir }}{2}$

b. Rata-rata piutang (Average Collection Period)

Menurut Syamsuddin (2004:49) untuk menegtahui rata-rata piutang (average account receivable) dapat di hitung dengan rumus yaitu :

Average Collection Period $=\frac{360}{\text { Tingkat Perputaran Piutang }}$

\section{Hasil dan Pembahasan}

Pada tahun 2012 Koperasi Bumi Mangupura Sejahtera merealisasikan kredit kepada masyarakat sebesar Rp 2.753.250.000 dalam analisis perputaran piutang kredit yang disalurkan tersebut merupakan piutang bagi Koperasi Bumi Mangupura Sejahtera. Dari jumlah piutang yang ada pada tahun 2012 tersebut terdapat piutang yang tertagih sebesar $\mathrm{Rp} 2.729 .530 .000$ dan piutang yang belum tertagih sebesar Rp 23.720.000.

Pada tahun 2013 Koperasi Bumi Mangupura Sejahtera merealisasikan kredit kepada masyarakat sebesar Rp 3.600.086.000 dalam analisis perputaran piutang kredit yang disalurkan tersebut merupakan piutang bagi Koperasi Bumi Mangupura Sejahtera. Dari jumlah piutang yang ada pada tahun 2012 tersebut terdapat piutang yang tertagih sebesar $\mathrm{Rp}$ 3.539.605.500 dan piutang yang belum tertagih sebesar Rp 60.480.500.

Pada tahun 2014 Koperasi Bumi Mangupura Sejahtera merealisasikan kredit kepada masyarakat sebesar $\mathrm{Rp} \quad 3.924 .539 .000$ dalam analisis perputaran piutang kredit yang disalurkan tersebut merupakan piutang bagi Koperasi Bumi Mangupura Sejahtera. Dari jumlah piutang yang ada pada tahun 2013 tersebut terdapat piutang yang tertagih sebesar Rp 3.880.208.030 dan piutang yang belum tertagih sebesar Rp 44.330.970. 
Tabel 1 Penilaian Tingkat Perputaran Piutang Tahun 2012-2014

\begin{tabular}{ll} 
& $\begin{array}{l}\text { Tingkat } \\
\text { Kiutang Perputaran } \\
\text { Receivable Turn Over } \\
\text { (RTO) }\end{array}$ \\
\hline Tinggi & $\geq 70$ kali \\
Sedang & $\geq 40$ kali -70 kali \\
Rendah & $\leq 40$ kali \\
\hline
\end{tabular}

Sumber : Koperasi Bumi Mangupura Sejahtera

Untuk perhitungan tingkat perputaran piutang tahun 2012-2014 adalah sebagai berikut: a. Analisis Tingkat Perputaran Piutang Tahun 2012

$$
\begin{aligned}
& \text { Rata }- \text { rata piutang }=\frac{\text { Piutang Awal }+ \text { Piutang Akhir }}{2} \\
& =\frac{R p 53.250 .000+R p 23.720 .000}{2} \\
& =\text { Rp } 38.485 .000
\end{aligned}
$$

b. Analisis tingkat perputaran piutang Tahun 2013

$$
\begin{aligned}
& \text { Rata }- \text { rata piutang }=\frac{\text { Piutang Awal }+ \text { Piutang Akhir }}{2} \\
& =\frac{R p 23.720 .000+R p 60.480 .500}{2} \\
& =\text { Rp } 42.100 .250 \\
& \text { Tingkat Perputaran Piutang }=\frac{\text { Kredit } \text { Pertahun }}{\text { Rata }- \text { rata Piutang }} \\
& =\frac{R p 3.600 .086 .000}{R p 42.100 .250} \\
& =85,51 \text { kali }
\end{aligned}
$$

C. Analisis tingkat perputaran piutang Tahun 2014

$$
\begin{aligned}
\text { Rata }- \text { rata piutang }=\frac{\text { Piutang Awal }+ \text { Piutang Akhir }}{2} \\
=\frac{R p 60.480 .500+R p 44.330 .970}{2} \\
=\operatorname{Rp} 52.405 .735
\end{aligned}
$$

Tingkat Perputaran Piutang $=\frac{\text { Kredit Pertahun }}{\text { Rata }- \text { rata Piutang }}$

$$
\begin{aligned}
& =\frac{R p 3.924 .539 .000}{R p 52.405 .735} \\
& =74,89 \text { kali }
\end{aligned}
$$


Tabel 2 Penilaian Average Collection Period Tahun 2012-2014

\begin{tabular}{ll} 
Kriteria & $\begin{array}{l}\text { Average } \\
\text { Period } \\
(A C P)\end{array}$ \\
\hline Tinggi & $\leq 12$ hari \\
Sedang & $\leq 12$ hari - 20 hari \\
Rendah & $\geq 20$ hari \\
ber : Koperasi Bumi Mangupura Sejahtera
\end{tabular}

Untuk perhitungan Average Collection Period tahun 2012-2014 adalah sebagai berikut:

1.

Tahun 2012

$$
\begin{aligned}
\text { Average Collection Period } & =\frac{360}{\text { Tingkat Perputaran Piutang }} \\
& =\frac{360}{71,54} \\
& =5 \text { hari }
\end{aligned}
$$

\section{Tahun 2013}

$$
\begin{aligned}
\text { Average Collection Period } & =\frac{360}{\text { Tingkat Perputaran Piutang }} \\
& =\frac{360}{85,51} \\
& =4 \text { hari }
\end{aligned}
$$

\section{Tahun 2014}

$$
\begin{aligned}
\text { Average Collection Period } & =\frac{360}{\text { Tingkat Perputaran Piutang }} \\
& =\frac{360}{74,89} \\
& =5 \text { hari }
\end{aligned}
$$

Setelah dilakukan perhitungan analisis tingkat perputaran piutang menggunakan 2 rasio antara lain tingkat perputara piutang (Receivable Turn Over) dan (Average Collection Period) pada Koperasi Bumi Mangupura Sejahtera. Hasil penelitian tingkat perputaran piutang (Receivable Turn Over) dan Average Collection Period (ACP) dilihat pada tabel 3. Sedangkan penilaian tingkat perputaran piutang (Receivable Turn Over) dan Average Collection Period (ACP) dilihat pada tabel 4.

\section{Tabel 3 Tingkat Perputaran Piutang dan Average Collection Period}

\section{Tahun}

\section{$2012 \quad 2013 \quad 2014$}

$\begin{array}{llll}\text { Tingkat } & & & \\ \text { Perputaran } & 71,54 & 85,51 & 74,89 \\ \text { Piutang } & \text { kali } & \text { kali } & \text { kali }\end{array}$

\section{Average}

Collection 5 hari 4 hari 5 hari

\section{Period}


Tabel 4 Penilaian Tingkat Perputaran Piutang dan Average Collection Period

\begin{tabular}{llll} 
& Penilaian & & \\
& 2012 & 2013 & 2014 \\
\hline $\begin{array}{l}\text { Tingkat } \\
\text { Perputaran } \\
\text { Piutang }\end{array}$ & Tinggi & Tinggi & Tinggi \\
$\begin{array}{l}\text { Average } \\
\begin{array}{l}\text { Collection } \\
\text { Period }\end{array}\end{array}$ & Tinggi & Tinggi & Tinggi \\
\hline
\end{tabular}

a) Tingkat Perputaran Piutang (Receivable Turn Over)

Dari hasil perhitungan tingkat perputaran piutang (Receivable Turn Over) dapat dapat kita lihat bahwa tingakat perputaran piutang Koperasi Bumi Mangupura Sejahtera dari tahun 2012 ke tahun 2014 mengalami kenaikan dan penurunan. Dari perhitungan yang dilakukan pada tahun 2012 didapatkan hasil tingkat perputaran piutang diperoleh yaitu sebesar 71,54 kali maka dapat dikatakan tingakat perputaran piutang pada tahun 2012 sangat tinggi. Sedangkan pada tahun 2013 jumlah tingkat perputaran piutang yang diperoleh yaitu sebesar 85,51 kali maka dapat dikatakan tingakat perputaran piutang naik dibandingkan tahun 2012 namun tingkat perputaran piutang tahun 2013 pada Koperasi Bumi Mangupura Sejahtera masih dapat dikatakan tinggi. Sedangkan pada tahun 2014 tingkat perputaran piutang kembali mengalami penurunan. Hasil perhitungan tingkat perputaran piutang yang didapatkan yaitu sebesar 74,89 kali. Dengan tingkat perputaran piutang sebesar 74,89 kali dapat dikatakan tingkat perputaran piutang tahun 2014 masih relatip tinggi.

Dari perhitungan yang dilakuakan, tingkat perputaran piutang akan berpengaruh terhadap tingkat kesehatan Koperasi Bumi Mangupura Sejahtera yaitu semakin tinggi perputaran piutang Koperasi Bumi Mangupura Sejahtera maka semakin baik pula dan sehat kondisi dari Koperasi Bumi Mangupura Sejahtera. Dengan rendahnya tingkat perputaran piutang yang terjadi pada Koperasi Bumi Mangupura Sejahtera tentunya dapat diatasi yaitu dengan cara memperketat kebijakan pemberian kredit misalnya dengan jalan memperpendek waktu pembayaran. Ini mungkin dapat mempengaruhi baik terhadap kondisi keuangan perusahaan. Semakin cepat piutang dibayarkan semakin baik bagi perusahaan, karena semakin cepat pula piutang menajadi kas.

b) Average Collection Period (ACP)

Pada perhitungan Average Collection Period (ACP) sangat dipengaruhi oleh besarnya nilai tingkat perputaran piutang. Pada Koperasi Bumi Mangupura Sejahtera waktu yang diperlukan untuk mengumpulkan piutang mengalami penurunan dan peningkatan dari tahun 2012 ke tahun 2014. Pada tahun 2012 rata-rata pengumpulan piutang berputar selama 5 hari, pada tahun 2013 rata-rata pengumpulan piutang berputar selama 4 hari sedangkan pada tahun 2014 rata-rata pengumpulan piutang berputar selama 5 hari, hal ini berarti secara rata-rata perusahaan mengumpulkan piutangnya dalam jangka waktu 5 hari, 4 hari dan 5 hari. Dengan rata-rata pengumpulan piutang selama 5 hari, 4 hari dan 5 hari dapat dartikan yaitu apabila perusahaan menetapkan jangka waktu kredit adalah 280 hari kepada para nasabah maka umur rata-rata piutang sebesar 5 hari, 4 hari dan 5 hari menunjukan usaha manajemen dalam mengumpulkan piutang pada tahun 2012, tahun 2013 dan 2014 sangat tinggi. 


\section{Simpulan dan Saran}

Berdasarkan perhitungan dan analisis yang telah diuraikan pada bab sebelumnya ada beberapa hal yang bisa disimpulkan yaitu:

Berdasarkan perhitungan tingkat perputaran piutang (Receivable Turn Over) dapat kita lihat bahwa tingkat perputaran piutang perusahaan dari tahun ke tahun mengalami peningkatan dan penurunan. Pada tahun 2012 jumlah RTO yang di peroleh yaitu 71,54 kali, pada tahun 2013 jumlah RTO yang di peoleh yaitu 85,51 kali sedangkan tahun 2014 yaitu sebesar 74,89 kali ini berarti semakin tinggi perputaran piutang suatu perusahaan semakin baik, perputaran piutang dapat di tingkatkan memperketat kebijaksanaan pinjaman. Semakin cepat syarat pembayaran semakin baik bagi perusahaan, karena semakin cepat modal kerja yang tertanam dalam bentuk piutang kembali menjadi modal atau kas, yang berarti semakin cepat perputaran piutang.

Average Collection Period (ACP) rasio ini menunjukan bahwa Koperasi Bumi Mangupura Sejahtera setiap tahunnya cukup baik. Berdasarkan data perhitungan ACP, hasilnya tergantung dari hasil perhitungan RTO. Pada tahun 2012 rata-rata pengumpulan piutang berputar selama 5 hari, pada tahun 2013 rata-rata pengumpulan piutang berputar selama 4 hari sedangkn pada tahun 2014 rata-rata pengumpulan piutang berputar selama 5 hari. Hal ini secara rata-rata perusahaan mengumpulkan piutangnya dalam jangka waktu 5 hari, 4 hari, dan 5 hari. Semakin besar RTO semakin baik bagi perusahaan karena modal yang terikat dalam pitang dapat kembali dengan cepat menjadi kas.

Melihat kecenderungan piutang mengalami penurunan dan kenaikan, maka periode berikutnya sebaiknya Koperasi Bumi Mangupura Sejahtera meningkatkan kegiatan yang mengarah pada upaya penagihan piutang tersebut, serta secara serius memperhatikan kredit yang diberikan agar sesuai prosedur yang ditetapkan.

\section{Daftar Pustaka}

Alex S, Nitisemito. 1991. Pembelajaran Perusahaan. Jakarta: Ghalia Indonesia

Anner Gregory , Pengertian Analisis tersedia pada http://carapedia.com/pengertian definisi analisis info.html

Ferdinansyah. 2007. Ekonomi. Jakarta: Topica.

Indriyo, 1980. Manajemen Keuangan. Yogyakarta: BPFE UGM.

Lukman, Syamsuddin. 1995. Manajemen Keuangan Perusahaan. Jakarta: PT Raja Grafinda Persada

Mantra, Anak Agung Gde, 1998. Metode Penelitian. Denpasar: Politeknik Negeri Bali

Munawir, 1995. http://www.Analisis Tingkat Perputaran Piutang. Blogspot. Com. 19 Maret 2012

Munawir. 2002. Analisis Laporan Keuangan. Yogyakarta: Liberty.

Kasmir, hal 92 Pengertian Kredit tersedia pada http://kafeilmu.com/2011/02/pengertian-kredit dan-dasar-hukumnya.html\#ixzzluuJOJwy4

Sucipto, Toto et al. 2006. Akuntansi Il a Bisnis dan Manajemen. Jakarta: Yudistira.

Syamsuddin. 2004. http//www. Analisis Tingkat Perputaran Piutang, blogspot 